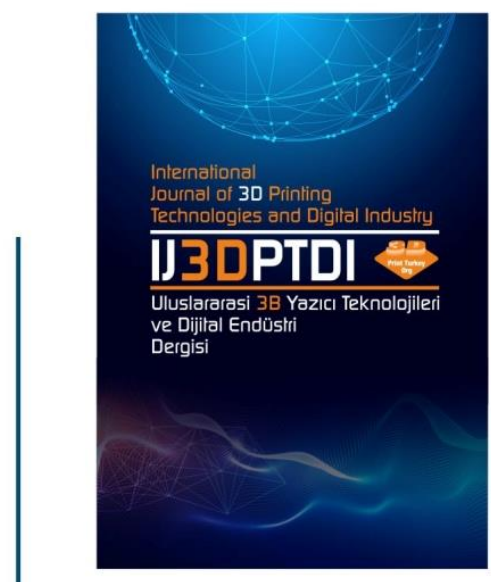

ULUSLARARASI 3B YAZICI TEKNOLOJILERI

VE DIJITAL ENDÜSTRI DERGISI

INTERNATIONAL JOURNAL QF 30 PRINTING TECHNOLOGIES AND DIGITAL INDUSTRY

IS5N:2602-3350 [Online]

URL: https://dergipark.org.tr/ij3dptdi

\title{
THE EFFECT OF MACHINING PROCESSES ON THE PHYSICAL AND SURFACE MORPHOLOGY OF TI6AI4V SPECIMENS PRODUCED THROUGH POWDER BED FUSION ADDITIVE MANUFACTURING
}

Yazarlar (Authors): Zihni Alp Çevik ${ }^{D}$, Koray Özsoy*iD, Ali Erçetin (D)

Bu makaleye şu şekilde atıfta bulunabilirsiniz (To cite to this article): Çevik Z.A, Özsoy K., Erçetin A, The Effect of Machining Process on The Pyhsical and Surface Morphology of Ti6Al4V Specimens Produced Through Powder Bed Fusion Additive Manufacturing" Int. J. of 3D Printing Tech. Dig. Ind., 5(2): 187-194, (2021). 


\title{
THE EFFECT OF MACHINING PROCESSES ON THE PHYSICAL AND SURFACE MORPHOLOGY OF TI6AI4V SPECIMENS PRODUCED THROUGH POWDER BED FUSION ADDITIVE MANUFACTURING
}

\author{
Zihni Alp Çevik ${ }^{\mathrm{a}}$ (D), Koray Özsoy ${ }^{\mathrm{b} *(\mathbb{D})}$, Ali Erçetin ${ }^{\mathrm{C}}$ (D) \\ a Adiyaman University, Besni Vocational School, Department of Mechatronics, TURKEY \\ ${ }^{\mathrm{b}}$ Isparta University of Applied Sciences, Senirkent Vocational School, Department of Electricity and Energy, \\ TURKEY \\ ${ }^{c}$ Bingöl University, Faculty of Engineering and Architecture, Department of Mechanical Engineering, TURKEY \\ *Corresponding Author: korayozsoy@isparta.edu.tr
}

(Received: 03.06.2021; Revised: 05.07.2021; Accepted: 08.08.2021)

\begin{abstract}
The most critical component of Industry 4.0, the new face of the machinery-manufacturing industry sector, is metal additive manufacturing. Laser-based additive manufacturing techniques are dominant for metal additive manufacturing today. In this study, the metal alloy studied is Ti-6Al-4V, one of the essential Ti alloys used in more than $50 \%$ of all commercial $\mathrm{Ti}$ applications. Ti-6Al-4V parts produced by additive manufacturing are used in the biomedical, aerospace-defence industry, and industrial areas due to their high strength, fatigue behaviour, fracture strength, good corrosion resistance, and biocompatibility. In the study, samples of Ti6Al4V alloy were produced with different manufacturing parameters by the direct metal laser sintering (DMLS) method, which is one of the powder bed fusion methods. Then, the surface qualities of the samples were processed by milling and wire EDM. The effects of machining operations on the surface roughness of the samples were investigated and compared with the surface roughness obtained from the samples produced by the DMLS method. After the optical microscope images of the samples were taken, the physical and surface morphology were examined. Although the mechanical properties of the parts manufactured by DMLS methods were higher, the samples with machining presented higher machinability with lower forces, lower surface roughness. the This is explained that mechanical properties of samples of Ti6Al4V alloy in additive manufacturing are highly dependent on the rapid cooling of the material. Results show that samples of Ti6Al4V manufactured by additive manufacturing has been possible using with machining.
\end{abstract}

Keywords: Additive Manufacturing. Ti6Al4V. DMLS. Machining. Surface Morphology

\section{INTRODUCTION}

Metals are converted into products by adding value through manufacturing methods such as machining, welding, powder metallurgy, casting, plastic forming, and unconventional manufacturing methods[1-3]. Machining is the general name of removing parts in the form of chips with cutting tools from the surface of the material to bring raw material to the desired final shape and size in a controlled manner $[1,2,4]$. Additive manufacturing is one of the non-traditional manufacturing methods. The basis of the additive manufacturing method is to add material layer by layer to produce parts from 3D solid model data, unlike traditional manufacturing methods [5]. Additive manufacturing methods are generally categorized into seven classes today. According to the technology used in additive manufacturing methods are classified such as Fused Deposition Modeling (FDM), Selective Laser Sintering (SLS), Selective Laser Melting (SLE), Electron Beam Melting (EBM), Stereolithography (SLA), Material Jetting, Binder Jetting, Laser Machining Net Forming, and Electron Beam Source [6]. Among these technologies, it has been seen that powder bed fusion systems are used more frequently in metal production [7]. Additive manufacturing has an improved design capability compared to machining 
methods, the ability to manufacture custom lightweight caged structures and manufacture lighter parts [8].

The variety of materials that can be used for the additive manufacturing process is currently increasing. The solid, liquid and gas-based raw materials are used to manufacture parts in additive manufacturing technologies. The additive manufacturing technologies are determined according to the form of the material used to build raw material. Most of the metal powders used in the additive manufacturing method are generally produced using well-known technologies for metal powder production. In additive manufacturing, process parameters such as the shape and size of the powder material, laser power, hatching speed, hatching distance, and layer thickness significantly affect the mechanical properties such as dimensional accuracy and surface quality part [8]. In the literature academic studies are examined, the materials used in additive manufacturing processes are steel and stainless steel $[9,10]$, titanium alloys [11], aluminium alloys [12], nickel-based alloys [13], cobalt-chromium alloys [14]. Titanium alloy material has high surface quality, high strength, excellent biocompatibility, low density, good corrosion resistance, high fatigue resistance, lightness, strength to shear deformation, and controllable porosity. Therefore, The $\mathrm{Ti}$ and Ti-alloys are extremely interesting for the additive manufacturing method [15]. Titanium alloys are used in various industries such as the aerospace industry, military industry, automotive, biomedical applications, dentistry, moulding.

Although additive manufacturing has many advantages over machining, it has some limiting disadvantages, such as surface finish and dimensional accuracy. In order to improve the surface quality of the parts produced by additive manufacturing, the parts are subjected to second processing after manufacturing [16]. Different methods such as laser polishing, chemical processes, ultrasonic cavitation, electromagnetic processes, and machining can be preferred to improve the surface quality of metal parts produced by additive manufacturing [17]. Surface quality improvement with machining, especially the turning process, is carried out in surface improvement processes of cylindrical parts. With surface improvement turning, the aim is to increase surface qualities by precision machining cylindrical parts. In surface improvement turning, the surface quality of the part depends on the cutting parameters, the geometry of the insert, the mechanical and metallurgical properties of the material and the elements in the cutting environment[18,19]. The Ti6Al4V alloys manufactured by powder bed Fusion additive manufacturing show higher machinability than commercial Ti6Al4V regarding its mechanical properties and the cutting force, roughness, burr formation and chips analysis [20].

This study is aimed to improve the surface quality of the samples produced from Ti6Al4V alloy with powder bed fed additive manufacturing method with different processing parameters. For this purpose, CNC milling was carried out with a cutting speed of $200 \mathrm{~m} / \mathrm{min}$, a feed rate of $0.05 \mathrm{~mm} / \mathrm{rev}$ and a cutting depth of $0.5 \mathrm{~mm}$. A wire cutting speed of $5 \mathrm{~m} / \mathrm{sec}$ was applied in the wire erosion cutting process using $0.25 \mathrm{~mm}$ diameter wire. The effects of machining operations on the surface roughness were investigated and compared with the surface roughness obtained in production with the additive manufacturing method. Optical microscope images of the samples were taken, and physical and surface morphology was examined. As a result, it has been determined that the machining method is a finishing process that can be used to increase the surface quality of the surfaces produced by the AM method.

\section{EXPERIMENTAL STUDIES}

The chemical composition and density of the Ti6Al4V powder material produced by the EOS M280 company used for the material of the samples produced with different parameters in the study are given in Table 1.

Table 1. Chemical and physical properties of Ti6Al4V metal powder [21]

\begin{tabular}{|l|c|c|c|c|c|c|c|c|}
\hline $\begin{array}{c}\text { Alloy } \\
\text { Element }\end{array}$ & Al & $\mathbf{V}$ & $\mathbf{O}$ & $\mathbf{N}$ & $\mathbf{C}$ & $\mathbf{H}$ & $\mathbf{F e}$ & $\mathbf{T i}$ \\
\hline wt. \% & $5.5-6.75$ & $3.5-4.5$ & $<2000 \mathrm{ppm}$ & $<500 \mathrm{ppm}$ & $<800 \mathrm{ppm}$ & $<150 \mathrm{ppm}$ & $<3000 \mathrm{ppm}$ & Balance \\
\hline Density & \multicolumn{10}{|l}{} & $4.42 \mathrm{~g} / \mathrm{cm}^{3}$ & \\
\hline Particle Size
\end{tabular}


The test specimens that were manufactured using Ti6Al4V metal powders in different processing parameters, were produced with the EOS M280 DMLS (direct metal laser sintering) device. In manufacturing with DMLS, factors such as the laser power, the scanning speed, the distance between the paths it travels, and the scanning distance affect the mechanical properties of the manufactured parts. In Equation 1, the energy density, which combines machining parameters in manufacturing with DMLS, is given. The test parameters used in the manufacture of the samples in the study are given in Table 2.

$$
E=P /(v . h . t)
$$

Here, $E$ stands for energy density, $P$ stands for laser power, $v$ stands for hatching speed, $h$ stands for hatching distance and $t$ stands for layer thickness.

Table 2. Different processing parameters of samples fabricated with DMLS

\begin{tabular}{|l|l|l|l|l|}
\hline No & $\begin{array}{l}\text { Laser Power } \\
(\mathrm{W})\end{array}$ & $\begin{array}{l}\text { Hatching } \\
\text { Speed } \\
(\mathrm{mm} / \mathrm{sn})\end{array}$ & $\begin{array}{l}\text { Hatching } \\
\text { Distance }(\mathrm{mm})\end{array}$ & $\begin{array}{l}\text { Energy Density } \\
(\mathrm{J})\end{array}$ \\
\hline 1 & 160 & 1000 & 0.07 & 2.28 \\
\hline 2 & 160 & 1250 & 0.07 & 1.42 \\
\hline 3 & 140 & 1000 & 0.07 & 2.00 \\
\hline 4 & 140 & 1250 & 0.09 & 1.24 \\
\hline
\end{tabular}

As shown in Figure 1, test samples were produced with different processing parameters by the DMLS method. In the powder bed fusion metal additive manufacturing method, the metal powder material is sintered layer by layer with laser energy density. The laser energy density used in joining the powder material and the parameters affecting the laser energy density effect the sintering quality of the powder. As a result of this, the results of the parts are affected, such as surface roughness.

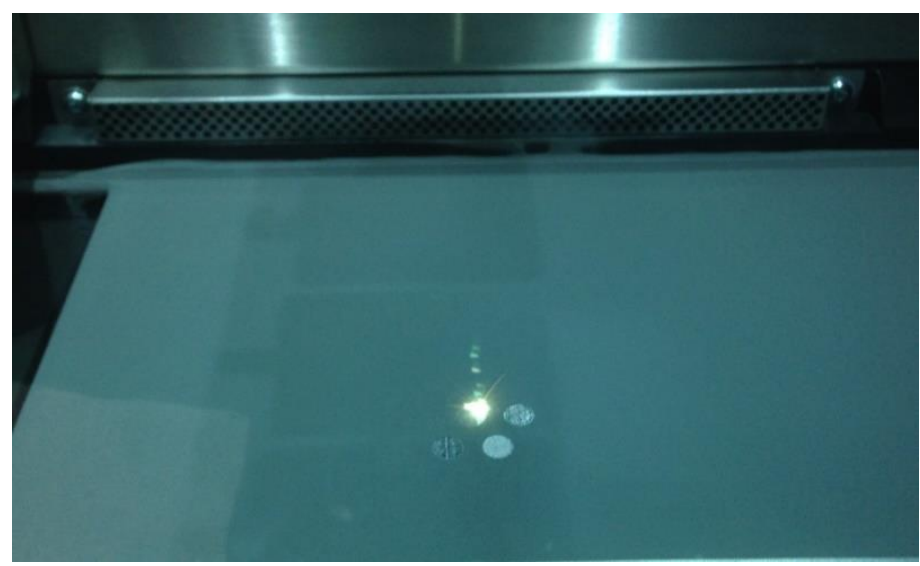

Figure 1. Sample image produced by DMLS method

Samples fabricated by the DMLS method with different parameters were processed using Wire Electrical Discharge Machining (WEDM) and Computer Numerical Control (CNC) machining processes. The parameters of the different processing techniques used in the experimental study are given in Table 3. Then, three measurements were made for each sample using an Insize brand, ISRC100 model surface roughness measuring device with $0.001 \mu \mathrm{m}$ sensitivity to measure the machined surfaces average surface roughness (Ra). An optical microscope was used to take images of the processed surfaces. Figure 2 shows the experimental setup and measuring devices. 
Table 3. WEDM and CNC parameters

\begin{tabular}{|c|c|c|c|}
\hline WEDM parameters & Value & CNC parameters & Value \\
\hline Wire material & CuZn37 & Cutting speed & $200 \mathrm{~m} / \mathrm{min}$ \\
\hline Open circuit voltage & $22 \mathrm{~V}$ & Feed rate & $0.05 \mathrm{~mm} / \mathrm{rev}$ \\
\hline Peak current & $9 \mathrm{~A}$ & Depth of cut & $0.5 \mathrm{~mm}$ \\
\hline Wire diameter & $0.25 \mathrm{~mm}$ & Cutting tool & Polycrystalline Diamond (PCD) \\
\hline Wire cutting speed & $5 \mathrm{~m} / \mathrm{sec}$ & \multicolumn{3}{|c|}{} \\
\hline
\end{tabular}

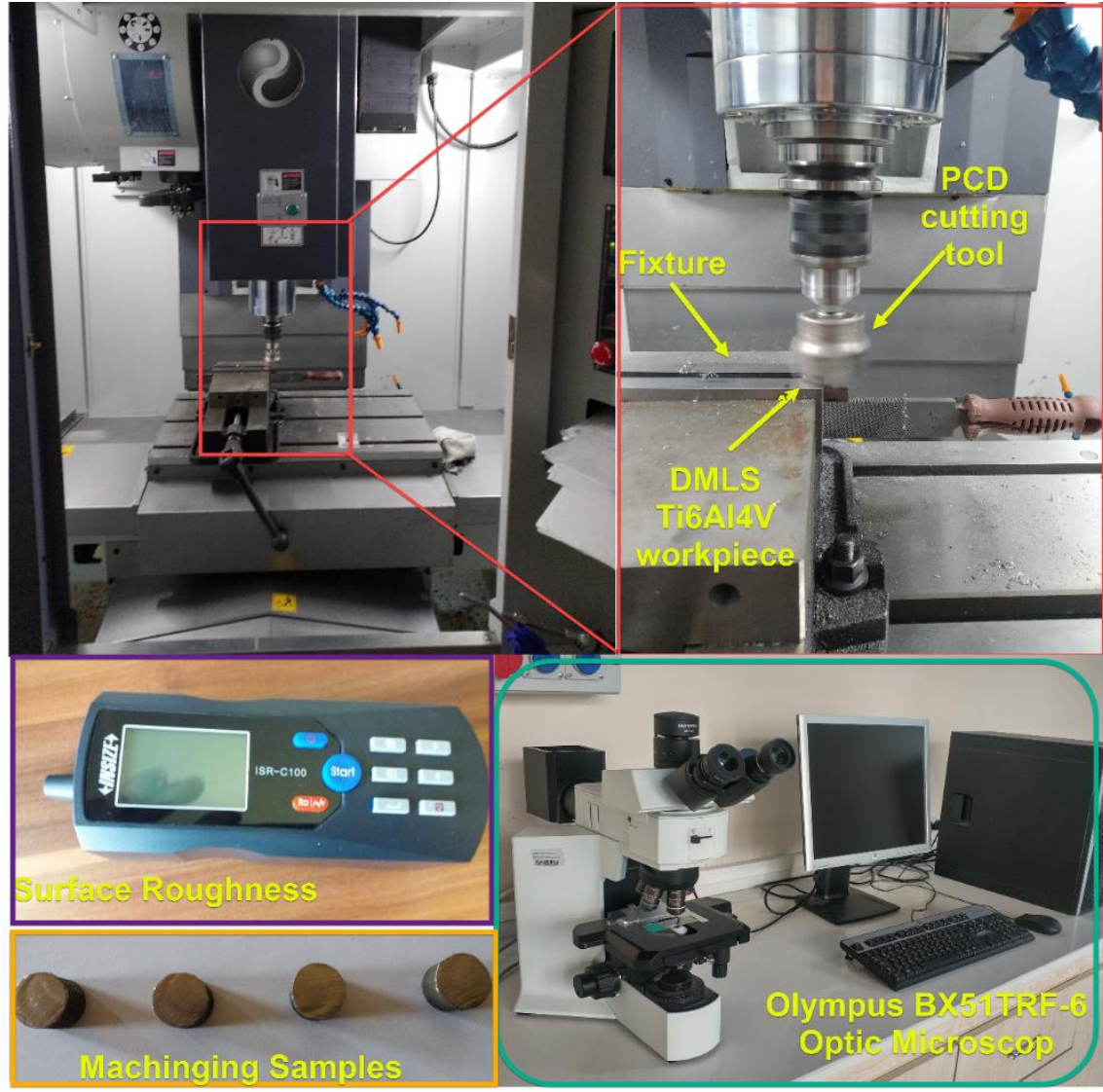

Figure 2. Experimental setup and measuring devices

\section{RESEARCH FINDINGS AND DISCUSSION}

\subsection{Effect of Different Machining Techniques on Surface Roughness}

As a result of the different processing techniques of the samples manufactured with DMLS, the surface texture is expressed by the surface roughness Ra. The surface roughness values of Ti6Al4V samples produced by the DMLS method with different processing parameters are given in Table 4 . As shown in Figure 3, the surface roughness values of the samples produced by the DMLS method are high. When the surface roughness values of the samples produced by the DMLS method were compared within themselves, it was determined that the average surface roughness value was expected to decrease when the minimum scanning speed $(1000 \mathrm{~mm} / \mathrm{sec})$ and maximum laser power $(160 \mathrm{~W})$ was applied, but on the contrary, it increased considerably. This situation is due to the application of high energy density $\left(2.28 \mathrm{~J} / \mathrm{mm}^{2}\right)$ per unit area (Sample No: 1) as compared in the literature. When the scanning distance and laser power are reduced gradually, it is seen in Figure 3 that the surface roughness values also decrease (Sample No: 2 and 3). However, when the maximum scanning speed $(1250 \mathrm{~mm} / \mathrm{s})$ and minimum laser power $(140 \mathrm{~W})$ were applied, the average surface roughness reached its maximum value (Sample No: 4). It is a common situation that the sample produced will have a porous structure as a result of the applied energy density falling below a certain level. 
Table 4. Surface roughness Ra $(\mu \mathrm{m})$ values of Ti6Al4V samples produced by DMLS method

\begin{tabular}{ccccc}
\hline Machining type & \multicolumn{5}{c}{ Sample No } \\
\cline { 2 - 5 } & 1 & 2 & 3 & 4 \\
\hline $\begin{array}{c}\text { DMLS } \\
\text { (Ra) }\end{array}$ & 8.18 & 7.38 & 6.98 & 9.69 \\
$\begin{array}{c}\text { WEDM } \\
\text { (Ra) }\end{array}$ & 3.042 & 2.84 & 2.31 & 3.092 \\
CNC & & & & 0.919 \\
(Ra) & 0.592 & 0.475 & 0.235 & \\
\hline
\end{tabular}

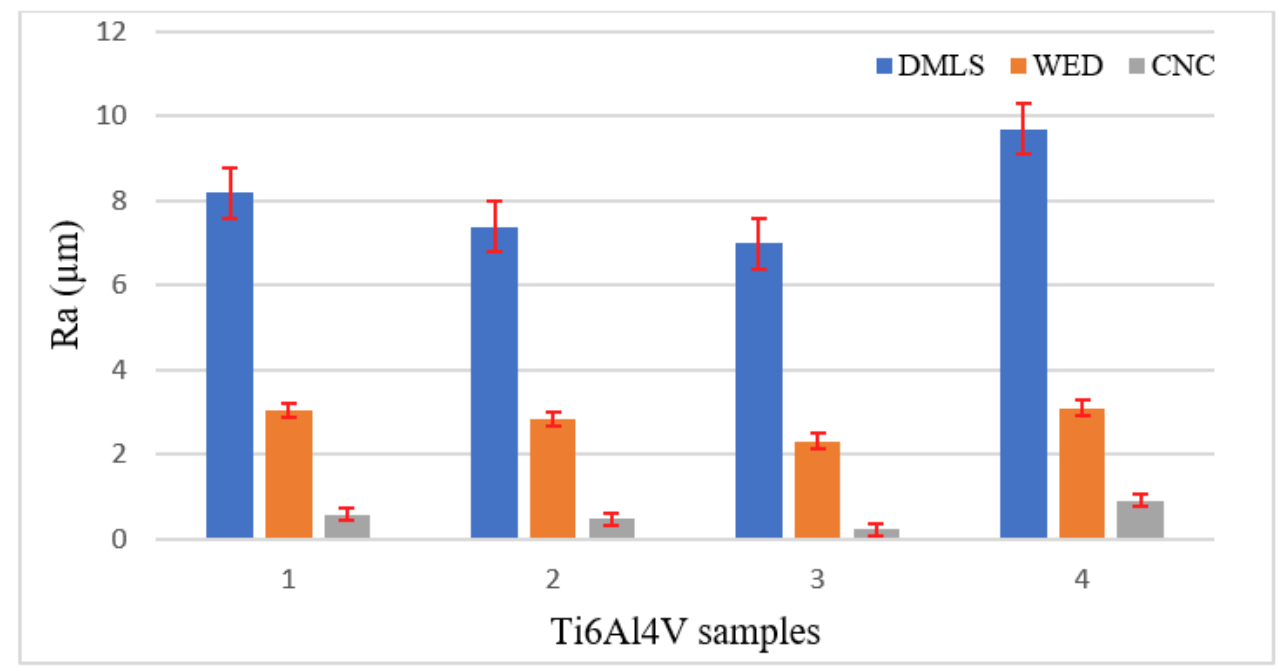

Figure 3. Ra surface roughness of Ti6Al4V samples

When the literature is examined, in the study of Greitemeier [22], the surface roughness value of the samples produced by the DMLS method with Ti6Al4V material is $\mathrm{Ra}=13 \pm 0.7 \mu \mathrm{m}$ in the production direction. In his study, Nicoletto [23] made surface roughness measurements to examine the fatigue behaviour of Ti6A14V material samples with the DMLS and EBM method, which is one of the powder bed fusion metal additive manufacturing methods. Then, while the surface roughness values in the production direction were $\mathrm{Ra}=3.3 \mu \mathrm{m}$ for the DMLS method, $\mathrm{Ra}=7.29 \mu \mathrm{m}$ for the $\mathrm{EBM}$ method proves that the surface roughness value of the samples produced with DMLS is always smaller than the EBM method. Here, the reason why the surface roughness is obtained at a low value due to production with DMLS is that completely melted laser traces characterize it. In Sharma's study [24], the samples were produced with 30, 45, 60, 75 and 90 angles, respectively, according to the production angle. The surface roughness $\mathrm{Ra}(\mu \mathrm{m})$ values were obtained at the mean measurement values of $39,27,18,8$, and 7 respectively.

\subsection{Surface Morphology}

The optical images of the surface morphology resulting from the application of CNC, DMLS and WEDM processes to the samples produced using parameters 4, where the highest Ra surface roughness values are obtained, are given in Figure 4. As a result of the CNC milling process, the top and bottom traces are seen in the surface morphology (Figure 4a). The fact that the minimum average surface roughness values were obtained due to CNC milling indicates that the level difference between the top and bottom traces in Figure 4a is quite low. In similar literature studies [25], the surface quality deteriorated when the distance difference between the bottom and top levels of the traces formed after the milling process increased and improved surface quality when this distance difference was minimal. It is seen that partly melted particles and laser ripples are formed on the surface after production with the additive manufacturing method (Figure 4b). In a similar study [26], laser ripples and partly melted 
particles were discovered on the surface of samples produced by metal additive manufacturing. It has been determined that these formations seriously affect the surface quality negatively. After the WEDM process, it was determined that the formed tops and pits were more regional (Figure 4c).
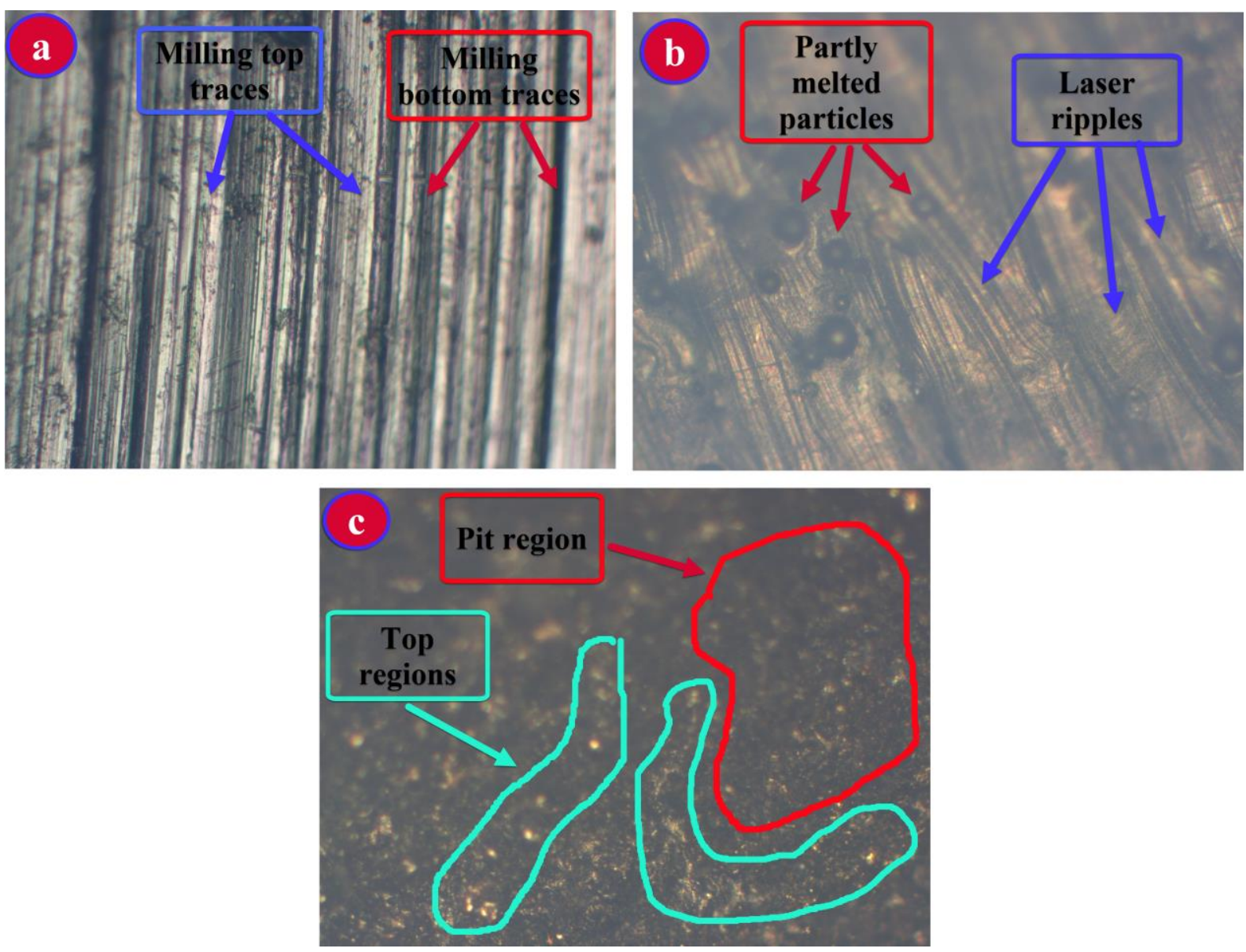

Figure 4. Optical images of Ti6Al4V samples produced with the parameter for sample-4 from the surface after different processing (a) CNC, (b) DMLS, (c) WEDM

\section{CONCLUSIONS}

As a result of the samples produced by the additive manufacturing method, subjected to WEDM cutting and $\mathrm{CNC}$ milling processes, significant changes were determined in the average surface roughness values.

The results of the present study follow:

- It has been observed that the processing parameters such as laser power, scanning speed and scanning distance applied during the production of the samples by the DMLS method affect the surface roughness.

- Surface roughness values, one of the biggest disadvantages of the additive manufacturing method, were high in the samples produced by the DMLS method.

- As a result of cutting with WEDM, it has been observed that the peaks and pits on the cutting surface are more regional. This situation increased the surface roughness ( $\mathrm{Ra}$ ) values of Ti6Al4V samples.

- It has been determined that the surface quality can be improved by applying an additional process such as $\mathrm{CNC}$ machining in cases where the surface quality of Ti6Al4V materials produced by additive manufacturing method, where sensitive surface quality is desired, is insufficient. 
- Detailed, the Ti6Al4V samples manufactured by DMLS methods were presented higher machinability with lower cutting forces, lower surface roughness due to rapid cooling of the material.

\section{REFERENCES}

1. Tezel, T., Topal, E.S., Kovan, V., "Hibrit imalat: Eklemeli imalat ile talaşlı imalat yöntemlerinin birlikte kullanılabilirliğinin incelenmesi”, International Journal of 3D Printing Technologies and Digital Industry, Cilt 2, Say1 3, Sayfa 60-65, 2018.

2. Erçetin, A., Aslantas, K., Özgün, Ö., "Micro-end milling of biomedical TZ54 magnesium alloy produced through powder metallurgy”, Machining Science and Technology, Vol. 24, Issue 6, Pages 924-947, 2020.

3. Akkoyun, F., Ercetin, A., Aslantas, K., Pimenov, D.Y., Giasin, K., Lakshmikanthan, A., Aamir, M. "Measurement of micro burr and slot widths through image processing: Comparison of manual and automated measurements in micro-milling", Sensors, Vol. 21, Issue 13, Pages 4432, 2021.

4. Kuntoğlu, M., Acar, O., Gupta, M.K., Sağlam, H., Sarikaya, M., Giasin, K., Pimenov, D.Y. "Parametric optimization for cutting forces and material removal rate in the turning of AISI 5140", Machines, Vol. 9, Issue 5, Pages 90, 2021.

5. Duman, B., Kayacan, M.C., "Doğrudan metal lazer sinterleme ergitme yöntemi ile imal edilecek parçanın mekanik özelliklerinin tahmini”, SDÜ Teknik Bilimler Dergisi, Cilt 7, Sayı 1, Sayfa 12-20, 2017.

6. Karakılınç U., Yalçın B. ve Ergene B., "Toz yataklı/beslemeli eklemeli imalatta kullanılan partiküllerin uygunluk araştırması ve partikül imalat yöntemleri”, Politeknik Dergisi, Cilt 22, Sayı 4, Sayfa 801-810, 2019.

7. Eklemeli Imalat Teknolojileri Yol Haritasi (Eityh) Odak Teknoloji Aği (Otağ) Sonuç Raporu, https://arge.ssb.gov.tr/Documents/Eklemeli_Imalat\%20_Teknolojileri_OTAG_Sonuc_Raporu.pdf , August 5, 2021.

8. Yalçın, B., Ergene, B., “Endüstride yeni eğilim olan 3-D eklemeli imalat yöntemi ve metalurjisi”, Uluslararas1 Teknolojik Bilimler Dergisi, Cilt 9, Sayı 3, Sayfa 65-88, 2017.

9. Oter, Z.C., Coskun, M., Akca, Y., Sürmen, Ö., Yılmaz, M.S., Özer, G., \& Koc, E. "Benefits of laser beam based additive manufacturing in die production”, Optik, Vol. 176, Pages 175-184, 2019.

10. Yasa, E., Kruth, J.P., "Microstructural investigation of Selective Laser Melting 316L stainless steel parts exposed to laser re-melting", Procedia Engineering, Vol. 19, Pages 389-395, 2011.

11. Kas, M., Yilmaz, O., "Radially graded porous structure design for laser powder bed fusion additive manufacturing of Ti-6Al-4V alloy”, Journal of Materials Processing Technology, Vol. 296, 117186, 2021.

12. Sagbas, B., "Post-processing effects on surface properties of direct metal laser sintered AlSi10Mg parts", Metals and Materials International, Vol. 26, Pages 143-153, 2020.

13. Wang, Y., Chen, X., Shen, Q., Su, C., Zhang, Y., Jayalakshmi, S., Singh, R.A., "Effect of magnetic Field on the microstructure and mechanical properties of Inconel 625 superalloy fabricated by wire arc additive manufacturing", Journal of Manufacturing Processes, Vol. 64, Pages 10-19, 2021.

14. Jevremović, D., Kojić, V., Bogdanović, G., Puškar, T., Eggbeer, D., Thomas, D., Williams, R. (2011). A selective laser melted $\mathrm{Co}-\mathrm{Cr}$ alloy used for the rapid manufacture of removable partial denture frameworks: Initial screening of biocompatibility. Journal of the Serbian Chemical Society, Vol. 76, Issue 1, Pages 43-52.

15. Kayacan, M., Delikanlı, Y., Duman, B., Özsoy, K., "Ti6A14V toz alaşımı kullanılarak sls ile üretilen geçişli (değişken) gözenekli numunelerin mekanik özelliklerinin incelenmesi”, Journal of the Faculty of Engineering and Architecture of Gazi University, Vol. 33, Issue 1, Pages 127-143, 2018. 
16. Kumbhar, N.N., Mulay, A.V., "Post processing methods used to improve surface finish of products which are manufactured by additive manufacturing technologies: A review", Journal of The Institution of Engineers India: Series C, Vol. 99, Issue 4, Pages 481-487, 2016.

17. Ermergen, T., Taylan, F., "Eklemeli imalat ile imal edilmiş metal parçalara uygulanan yüzey bitirme işlemleri”, SDU Uluslararası Teknolojik Bilimler Dergisi, Cilt 12, Sayı 1, Sayfa 45-55, 2020.

18. Ratnam, M.M., "Factors affecting surface roughness in finish turning", Comprehensive Material Finishing, Vol. 1, Pages 1-25, 2017.

19. de Oliveira Campos, F., Araujo, A. C., Munhoz, A. L. J., Kapoor, S. G. "The influence of additive manufacturing on the micromilling machinability of Ti6Al4V: A comparison of SLM and commercial workpieces”, Journal of Manufacturing Processes, Vol. 60, Pages 299-307, 2020.

20. He, C.L., Zong, W.J., Zhang, J.J., "Influencing factors and theoretical modeling methods of surface roughness in turning process: State-of-the-art", International Journal of Machine Tools and Manufacture, Vol. 129, Pages 1526, 2018.

21. Electro Optical Systems. Material data sheet: EOS Titanium Ti64. Munich, Germany: EOS. http://gpiprototype.com/images/PDF/ EOS_Titanium_Ti64_en.pdf. Accessed May 2, 2021.

22. Greitemeier, D., Dalle Donne, C., Syassen, F., Eufinger, J., Melz, T., "Effect of surface roughness on fatigue performance of additive manufactured Ti-6Al-4V", Materials Science and Technology, Vol. 32, Issue 7, Pages 629-634, 2016.

23. Nicoletto, G., Konečná, R., Frkáň, M., Riva, E. "Surface roughness and directional fatigue behavior of as-built EBM and DMLS Ti6Al4V”, International journal of fatigue, Vol. 116, 140-148, 2018.

24. Sharma, M., \& Soni, M., "Direct metal laser sintering of Ti6Al4V alloy for patient-specific temporo mandibular joint prosthesis and implant”, Materials Today: Proceedings, Vol. 38, Pages 333-339, 2021.

25. Erçetin, A., Aslantaş, K., Perçin, M., "Micro milling of tungsten-copper composite materials produced through powder metallurgy method: Effect of composition and sintering temperature", Journal of the Faculty of Engineering and Architecture of Gazi University, Vol. 33, Issue 4, Pages 1369-1381, 2018.

26. Cabanettes, F., Joubert, A., Chardon, G., Dumas, V., Rech, J., Grosjean, C., Dimkovski, Z. "Topography of as built surfaces generated in metal additive manufacturing: A multi scale analysis from form to roughness", Precision Engineering, Vol. 52, Pages 249-265, 2018. 